\section{Can We Grow Organic or Conventional Vegetables Sustainably Without Cover Crops?}

\author{
Eric B. Brennan ${ }^{1}$
}

ADDITIONAL INDEX wORDs. vegetable production, nitrate leaching, high-value crops, farming, green manure, catch crop, soil management, nutrient management

SUMMARY. Vegetable and fruit consumption patterns in the United States indicate that most people need to eat far more fruits and vegetables to meet the current nutritional guidelines for a healthy diet. Following these guidelines would require more than doubling the harvested acreage for fruits and vegetables and could have serious environmental implications if unsustainable production practices were used. This situation will likely intensify with population growth and climate change. To answer the title question (can we grow organic or conventional vegetables sustainably without cover crops?), this paper focuses on the high-input, tillageintensive vegetable production practices in the Salinas Valley of California, a region often called "the Salad Bowl of America." This region has a serious problem of nitrate contamination of the groundwater that occurred as the agricultural systems here shifted from agronomic to high-value horticultural crops [primarily vegetables and strawberries (Fragaria $\times$ ananassa)] over the past several decades. This raises questions about the sustainability of past and current vegetable production practices and indicates the need for a radical paradigm shift in nutrient management. Cover cropping is well recognized as a "best management practice" in vegetable production systems, but is still relatively uncommon in many of the most important vegetable production regions in the United States, including the Salinas Valley. It is argued that cover crops are an essential part of sustainable vegetable production because they provide a complex suite of unique ecosystem services during fallow periods that complement best management practices during cash crop periods. The reasons that cover crops are uncommon here are discussed and three alternative cover cropping strategies are described to potentially increase adoption of cover cropping in vegetable rotations. These strategies are focused on reducing residue management challenges and include a novel strategy to extract the juice from nitrogen-rich, immature cover crops for use as a liquid organic fertilizer in subsequent cash crops.

$\mathrm{E}$ very 5 years, the U.S. Department of Agriculture (USDA) releases dietary guidelines to help Americans choose nutritious foods to prevent chronic, diet-related diseases and promote better health. Nutrient-rich vegetables are a critical part of this, yet current eating patterns show that less than 20\% of Americans eat the recommended amounts

USDA-ARS, Organic Crop Production, 1636 East Alisal Street, Salinas, CA

This paper was part of the workshop "Soil Health and Implication in Organic Nutrient Management on Vegetable Production" held 5 Aug. 2015 at the ASHS Annual Conference, New Orleans, LA, and sponsored by the Organic Horticulture Working Group

I appreciate the comments by Jim Leap, Paul Brennan, Michael Cahn, Richard Smith, Mathieu Ngouajio, and three anonymous reviewers that helped to improve this manuscript. I also appreciate the input on the challenges and benefits of cover cropping in vegetable systems provided by many of the authors of the publication (Cover cropping for vegetable production: A growers handbook. University of California, 2011)

${ }^{1}$ Corresponding author. E-mail: eric.brennan@ars. usda.gov.

doi: 10.21273/HORTTECH03358-16 of vegetables (USDA, 2015). This discrepancy is particularly apparent for well-known dark-green vegetables [e.g., kale (Brassica oleraceae var. acephala), broccoli (B. oleraceae var. italic), and romaine lettuce (Lactuca sativa) ] and other lesser-known ones [e.g., purslane (Portulaca oleracea) and amaranth (Amaranthus sp.)]. If Americans followed these guidelines, this would have major implications for vegetable farmers, and for the environment where these high-input and tillage-intensive crops are grown. For example, Buzby et al. (2006) estimated that the land devoted to dark-green vegetables alone would need to increase from 291,000 to 799,000 harvested acres in the United States. For perspective, consider the so-called "Salad Bowl of America" in the Salinas Valley of Monterey County, CA, which is one of the most intensive agricultural areas in the world for highvalue vegetable production. About 300,000 acres of vegetables valued at over $\$ 3$ billion are produced here annually (Monterey County Agricultural Commissioner, 2014). Therefore, the additional area needed to provide Americans with the recommended guidelines for dark-green vegetable alone would be more than twice the annual harvested area for all vegetables in the Salinas Valley! That is a lot of land, labor, fertilizer, tillage, and potential nitrate leaching and carbon emissions depending on how these vegetables are grown and marketed.

Although it is unlikely that dietary patterns will shift rapidly toward increased vegetable consumption, it is important to consider the broad links between human and environmental health (Patz et al., 2000; Wall et al., 2015 ), and rigorously address one of the grand challenges of the 21st century - the need to produce more food with low pollution, what some scientists call "Mo Fo Lo Po" (Davidson et al., 2015). This is a particularly daunting task for vegetable farmers because there is ample evidence that many of the common, current, and past vegetable production practices in regions like the Salinas Valley and elsewhere are unsustainable. Perhaps the best evidence of this in California is in the Salinas Valley's groundwater that over decades has become contaminated with the nitrates derived primarily from fertilizers (Harter et al., 2012). This nitrate problem and other groundwater problems (i.e., salt water intrusion from the nearby Pacific Ocean due to

\begin{tabular}{llll}
\hline $\begin{array}{l}\text { Unit } \\
\text { To convert U.S. to SI, } \\
\text { multiply by }\end{array}$ & U.S. unit & SI unit & $\begin{array}{l}\text { To convert SI to U.S., } \\
\text { multiply by }\end{array}$ \\
\hline 0.4047 & acre(s) & $\mathrm{ha}$ & 2.4711 \\
3.7854 & gal & $\mathrm{L}$ & 0.2642 \\
9.3540 & gal/acre & $\mathrm{L} \cdot \mathrm{ha}^{-1}$ & 0.1069 \\
2.54 & inch(es) & $\mathrm{cm}$ & 0.3937 \\
1.1209 & lb/acre & $\mathrm{kg} \cdot \mathrm{ha}^{-1}$ & 0.8922 \\
1 & ppm & $\mu \mathrm{g} \cdot \mathrm{g}^{-1}$ & 1 \\
2.2417 & ton(s)/acre & $\mathrm{Mg} \cdot \mathrm{ha}^{-1}$ & 0.4461
\end{tabular}


overpumping of groundwater) occurred gradually during the shift from relatively low-input, rain-fed agronomic crops to high-input, irrigated high-value crops like vegetables and strawberries (Rosenstock et al., 2014).

A variety of potential solutions to address the nitrate leaching problem and improve groundwater quality have been proposed, including regulations to reduce nitrogen $(\mathrm{N})$ fertilizer use (i.e., fertilizer tax, cap, and trade programs) (Medellin-Azuara et al., 2013) and best management practices (i.e., using appropriate crop fertilizer templates, efficient irrigation management, cover cropping) (Di and Cameron, 2002; Hartz, 2006; Shepherd and Chambers, 2007). But solving this complex nitrate problem is expected to take decades and require significant changes in agricultural practices. In this opinion paper, I focus on the potential role of cover crops in vegetable systems based on 1) my understanding of the scientific basis for cover cropping, 2) my handson experience in commercial-scale, for-profit production of vegetables in the long-term systems experiment at the organic research farm that I manage, and 3) my efforts to transfer our research results to organic and conventional farmers in the Salinas Valley for more than a decade. I use the term "cover crop" broadly to encompass noncash crops that are used for a variety of purposes, and which are sometimes given more specific terms (i.e., catch crops and green manures). It is important to highlight that although the ideas presented are most likely applicable to intensive, vegetable production in regions like the Salinas Valley with a Mediterranean climate (i.e., rainy, mild winters and warm, dry summers between about lat. $30^{\circ}$ and $45^{\circ}$ ), they may also be relevant to intensive vegetable production elsewhere.

\section{Clarifying the title question: Can we produce organic or conventional vegetables sustainably without cover crops?}

Before answering the complex title question, let me clarify it. First, I am referring to winter cover crops like cereal rye (Secale cereale) and brassicas [e.g., mustard (Sinapis alba)] that are excellent scavengers of leftover nitrate from previous vegetable crops; Meisinger et al.(1991) highlighted that "non-legumes are about three times more efficient than legumes at reducing $\mathrm{N}$ leaching." In the Salinas Valley, these cover crops can be grown during the rainy period (i.e., October to February) when fields are typically fallow (Brennan and Boyd, 2012a). Although cover crop mixtures of $\mathrm{N}$-fixing legumes and nonlegumes may also be useful, our research has shown that integrating these mixes with vegetable rotations is more complex and questionable due to challenges with weed suppression and productivity of the legume component in soils where there are excessive amounts of $\mathrm{N}$ heading into the rainy winter (Brennan, 2014; Brennan and Boyd, 2012a; Brennan et al., 201la, $2011 b)$.

Second, I am referring to commercial-scale vegetable production where there are relatively strict quality standards (size, color, shape, etc.). These standards can vary somewhat depending on market fluctuations but apply to the vast majority of vegetables in the Salinas Valley that are sold wholesale for national and international markets. These cosmetic standards are typically not as important for produce that is direct marketed to local consumers through farmers markets or community-supported agricultural models (Adam, 2006).

Third, my question refers to high-value and high-input vegetables [e.g., lettuce, broccoli, celery (Apium graveolens var. dulce)] that are targeted for fresh consumption, and with a few exceptions (i.e., baby leaf spring mixes) are harvested by hand. Typical production costs for these types of vegetables in California often range from $\$ 5000$ to $\$ 10,000$ per acre (Dara et al., 2012; Tourte et al., 2015). Given the high value of land in the Salinas Valley (i.e., $\$ 1500$ to $\$ 3000$ per acre per year rent), rotations are typically focused only on high-value horticultural crops (i.e., vegetables and strawberries), as opposed to areas with lower land value where growers may have more flexibility to rotate high- and lower-value crops (i.e., agronomic or forage crops). These high-value systems are often heavily fertilized and irrigated to achieve high yields from multiple vegetable plantings on each field annually. Furthermore, soil nitrate levels can be quite high [i.e., $>80 \mu \mathrm{g}$ nitrate $\mathrm{N}$ per gram dry soil (0 to $15 \mathrm{~cm}$ depth)] in the fall before the typical, rainy, winter fallow period (Jackson et al., 1993). These crops usually require numerous tillage passes to ensure a uniform seed bed, control weeds, break up compaction from harvest operations, and hasten decomposition of previous crop residue. It is important to highlight that although USDA National Organic Program standards prohibit specific inputs (e.g., synthetic nitrogen fertilizers, conventional pesticides), in many regards, organic and conventional vegetable farms in the Salinas Valley are often relatively similar with regard to nutrient management practices (i.e., conventional fertilizers are substituted with pelleted and liquid organic fertilizers in certified organic systems); this "conventionalization" of organic agriculture has generated ongoing academic debate (Buck et al., 1997; Guthman, 2004; Sutherland, 2013). The yields of organic and conventional vegetable systems are often quite similar in the Salinas Valley, and hence the risk of nutrient leaching losses can be high in both types of systems (Kirchmann and Bergstrom, 2001).

Fourth, by "sustainable" I mean a production system that is profitable, provides a good quality of life for all members of the agricultural community, and ensures stewardship of our natural resources (Sustainable Agriculture Research and Education, 2010). Another definition of sustainability that I find helpful is "meeting current needs in ways that leaves options for future generations" (Denison, 2012). My discussion here is most relevant to the environmental stewardship and profitability components of sustainability. The title question refers to both organic and conventional vegetables because in my opinion, agricultural sustainability is far more complex than whether a system is conventional or certified organic.

\section{My answer}

Given these clarifications, unfortunately, I do not think that we can produce high-value and high-input organic or conventional vegetables sustainably on a commercial scale, in 
regions like the Salinas Valley, without winter cover crops. The primary reason that I think cover crops are essential in vegetable production is due to their ability to provide a complex and unique suite of critical ecosystem services [e.g., soil carbon sequestration, beneficial insect conservation, weed suppression, erosion control, nitrate retention (Schipanski et al., 2014)] during fallow periods and beyond, that complement best management practices during cash crop periods (Hartz, 2006). Integrating cover crops regularly into vegetable rotations can potentially help to facilitate a radical, and what many would consider a much needed, paradigm shift in the focus of many of our agricultural systems. This shift would entail 1) moving away from short-sighted thinking that is focused primarily on cash crops, and toward long-term, systems thinking that requires a more holistic, intensive management approach; 2) placing more emphasis on addressing the causes of problems than the symptoms; and 3 ) greater investment in the soil, water, and people that are necessary to produce the crops. I like to think of this new management paradigm for highvalue crops as "out of the produce box thinking." This shift is consistent with what Drinkwater and Snapp (2007) call "an ecosystem-based approach to improving nutrient use efficiency," and where they highlighted that "replacing bare fallows with appropriate cover crops should be a top priority of nutrient management programs." I often consider winter cover cropping as a way to give the soil a "meaningful rest" so that it can continue to function efficiently during the subsequent cash cropping periods.

I prefaced my answer to my title question with "unfortunately," because I am well aware of the systemic and monumental challenges involved with trying to integrate cover crops into vegetable systems in regions like the Salinas Valley. However, the industry here is extremely innovative and has made large improvements in resource use efficiency in the past. Here is one example that was highlighted in the 1990 Crop Report for Monterey County:

In 1930, 100 gallons of water were required to produce one head of lettuce. Now in 1990 it takes about
10 gallons. This large improvement in water use efficiency did not just happen. It was the result of long term water use studies to improve efficiency, and constantly improving technology and methods. These improvements enabled growers to produce more, while using less water.

Similar improvements are needed with nutrient use efficiency in vegetable systems using a suite of best management practices including cover crops. And the 2013 Crop Report for Monterey County (Monterey County Agricultural Commissioner, 2013) provides evidence of increasing interest in cover cropping and other best management practices here. For example, the report's cover includes a photograph of a child looking through a picture frame subtitled "Stewardship for our Future," and mentions cover crops three times and highlights them in two photographs. To my knowledge, this was the first time "cover crop" or "soil health" has been mentioned in a crop report for this region and illustrates "out of the produce box thinking." California Food and Agriculture Code 2279 requires that county agriculture commissioners produce these annual report to document the acreage and value of agricultural products in the county. I believe that expanding these reports to include winter cover cropped acres may be a cost-effective "social nudge" (Thaler and Sustein, 2008) to encourage the adoption of this best management practice. It is encouraging to see that the 2012 USDA Consensus on Agriculture took the unprecedented step to begin collecting data on cover cropped acreage which included 10.3 million acres of the 315 million acres of harvested land (i.e., 3.3\%) (USDA, 2014). This information combined with studies on cover crop adoption (Dunn et al., 2016; Singer and Nusser, 2007) can play an important role in understanding how to increase adoption.

The next important and hard question is: How do we (i.e., scientists, farm advisors, and consumers) help farmers in regions like the Salinas Valley transition to more sustainable vegetable production systems with cover crops? Before I propose a potential path forward, in the following section, I will first explain some challenges with cover cropping in the Salinas Valley.

\section{Why is winter cover cropping uncommon in high-value, high-input vegetable production systems?}

To my knowledge, there is no published quantitative data on the prevalence of cover cropping in the Salinas Valley; however, satellite images during the winter provide ample visual evidence of the lack of vegetative cover in production fields from cover crops or cash crops (Fig. 1). It is estimated that less than $5 \%$ of the vegetable land here is cover cropped annually (R. Smith, personal communication). It is important to highlight that there are several studies that have documented the lack of cover cropping on many organic vegetable farms in California (Bowles et al., 2014; Bustamante and Hartz, 2015; Guthman, 2000) and discussed the reasons for this (Hartz and Johnstone, 2006). Juggling balls can be a useful analogy to understand the challenges of cover cropping (Brennan et al., 2014). To put this in the context of the Salinas Valley, imagine that a grower here needs to produce two vegetable crops in each field annually between February and October. A red ball can represent the first crop (broccoli) and a blue ball can represent the second crop (romaine lettuce). A rotation (i.e., juggling pattern) with these two crops (i.e., balls) requires skill but is not overly challenging to achieve. Adding a third ball to this rotation, a green one that represents a cover crop, makes the rotation much more intense and challenging to manage, and it increases the risk of dropping a ball (i.e., cash crop failure). This is particularly true when we consider the diversity of crops and fields that the typical grower manages, and the economic pressure they face due to the high cost of agricultural land rent and the high production costs involved. It is important to highlight that lettuce production here is often not very profitable (Hartz, 2002). In my experience, much of the challenge and risk with cover cropping in tillage-intensive vegetable systems is related to cover crop residue management when fields are transitioned from a cover crop to the next cash crop. This is especially 


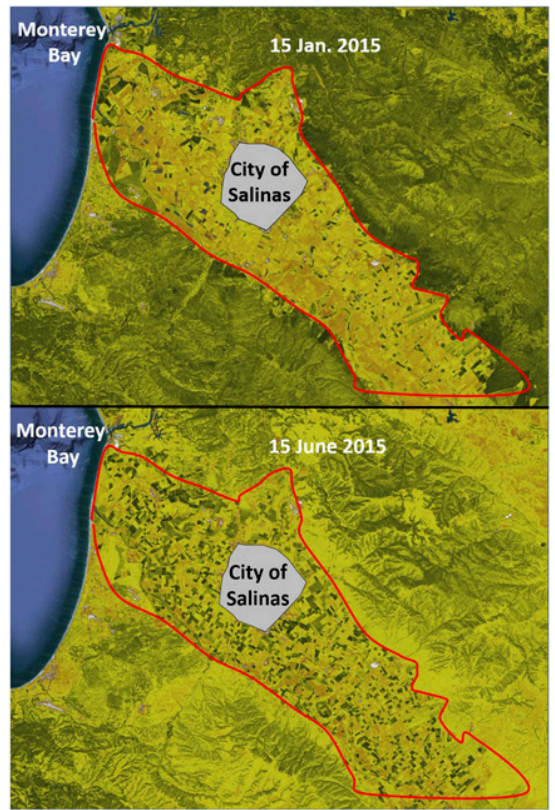

Fig. 1. Satellite images of the Salinas Valley in Jan. 2015 (top) vs. June 2015 (bottom). The area outlined in red in the center of the image is the valley floor where the majority of the intensive vegetable production occurs. The green color is indicative of vegetation cover. Note that during winter (top), the uncultivated areas surrounding the valley are green while the majority of intensively cropped area lack vegetation and are bare fallowed. In contrast, green cover from intensive cropping increases in summer (bottom), while the area surrounding the valley dries and has less green cover. Images are from the Terrestrial Observation and Prediction System, Satellite Irrigation Management Support, and the National Aeronautics and Space Administration.

true with small-seeded vegetables, where typical planting and cultivation equipment are not designed to operate efficiently with cover crop residue also known as "trash." Unpredictable spring rainfall is another important factor that can delay the incorporation of cover crop residue and early spring vegetable plantings and potentially increase the opportunity cost of cover cropping.

\section{Focusing on "trash" may help farmers use cover crops to clean up agricultural systems}

A potentially useful approach to increase cover crop adoption in intensive vegetable systems may be to develop strategies that minimize the challenges with large amounts (i.e., 5 to $8 \mathrm{Mg} \cdot \mathrm{ha}^{-1}$ ) of relatively tough cover crop residue that is typical following a standard cover crop. This standard cover cropping approach was used during the first 8 years of intensive, commercial-scale vegetable production in the ongoing Salinas Organic Cropping Systems experiment where the cover crop or fallow systems (October to February/March) were usually followed by transplanted lettuce and transplanted broccoli (Brennan and Boyd, 2012a). As manager and leader of this experiment, which required me to do lots of tractor work during the first several years, I quickly became frustratingly aware of the serious challenges of residue management with the standard cover cropping approach. For example, while the more sustainable systems in our experiment (with frequent cover crops) had several benefits (e.g., much higher vegetable yields, improved soil quality), these benefits were at the cost of 1 month or more delay in spring vegetable planting. This delay was necessary to allow adequate decomposition of the incorporated cover crop biomass, especially in the systems where a pure rye cover crop was used; mature rye residue tends to be lower quality than residue of mustard or legume-rye mixes (Brennan et al., 2013), which slows decomposition of the rye relative to the other cover crops. This opportunity cost explains the lower cash cropping intensity of fields that are cover cropped frequently (i.e., 1.5 to 2 crops per year) vs. those with a bare winter fallow ( 2 to 2.5 crops per year) (Klonsky and Tourte, 2011).

\section{Three innovative cover cropping strategies for vegetable systems}

The following are three innovative strategies to potentially reduce the challenges of residue management and thus increase the likelihood of cover crop adoption in vegetable systems. I envision that growers could potentially rotate between standard cover cropping and alternative strategies to optimize nutrient cycling, pest control, groundwater recharge, and overall soil health on their farm.

LOW-RESIDUE COVER CROPS IN FURROW вOTTOMs. This strategy was developed by University of California farm advisors to minimize winter runoff in plastic mulch-covered strawberry beds, or winter fallow vegetable beds (Cahn et al., 2006; Cahn and Miyao, 2011; Smith and Cahn, 2007). My discussion will focus on the vegetable system (Fig. 2).

The way this works in fallow vegetable beds is that in October to November, a cereal cover crop [i.e., rye or winter dormant triticale $(x$ Triticosecale)] seed is broadcast in the furrow bottoms at a relatively high seeding rate followed by a tillage tool to shallowly incorporate the seed. Ideally, this occurs just before rain to promote germination of the cover crop. About 50 to $60 \mathrm{~d}$ after planting, the cover crop is sprayed with a broad spectrum herbicide (i.e., glyphosate) to kill it. By this time, there is relatively little shoot biomass (i.e., $\approx 1$ to $2 \mathrm{Mg} \cdot \mathrm{ha}^{-1}$, oven-dry weight), which decomposes sufficiently over the next several weeks or more to allow for standard shallow tillage (i.e., chiseling of furrow bottoms, followed by rolling cultivation to incorporate residue, and bed shaping) to prepare the bed for spring planting on the same schedule as if the field had been bare fallowed.

Compared with bare fallow vegetable beds, this low-residue strategy with a rye cover crop reduced runoff by $95 \%$, sediment loss by more than $99 \%$, and soluble nutrient $\mathrm{N}$ and phosphorus losses in runoff by $96 \%$ and 95\%, respectively (Smith et al., 2011). These benefits can drastically reduce the amount of nutrient and pesticide runoff into the watershed, and increase groundwater recharge. However, the low biomass residue is generally not effective at reducing nitrate leaching, and thus seems most appropriate for fields with low to moderate levels of residual soil nitrate in the fall, and where there is a high runoff potential. Due to the challenge with mechanically killing immature cereal cover crops, this strategy is also best suited for conventional systems where systemic herbicides can be used. However, it may be possible to modify this for organic farms by using mustard cover crops that are relatively easy to kill mechanically with mowing, tillage, or crimping. Warm season cover crops [e.g., sudangrass (Sorghum bicolor ssp. drummondii)] are also showing promise in furrow bottoms when they are planted in early 


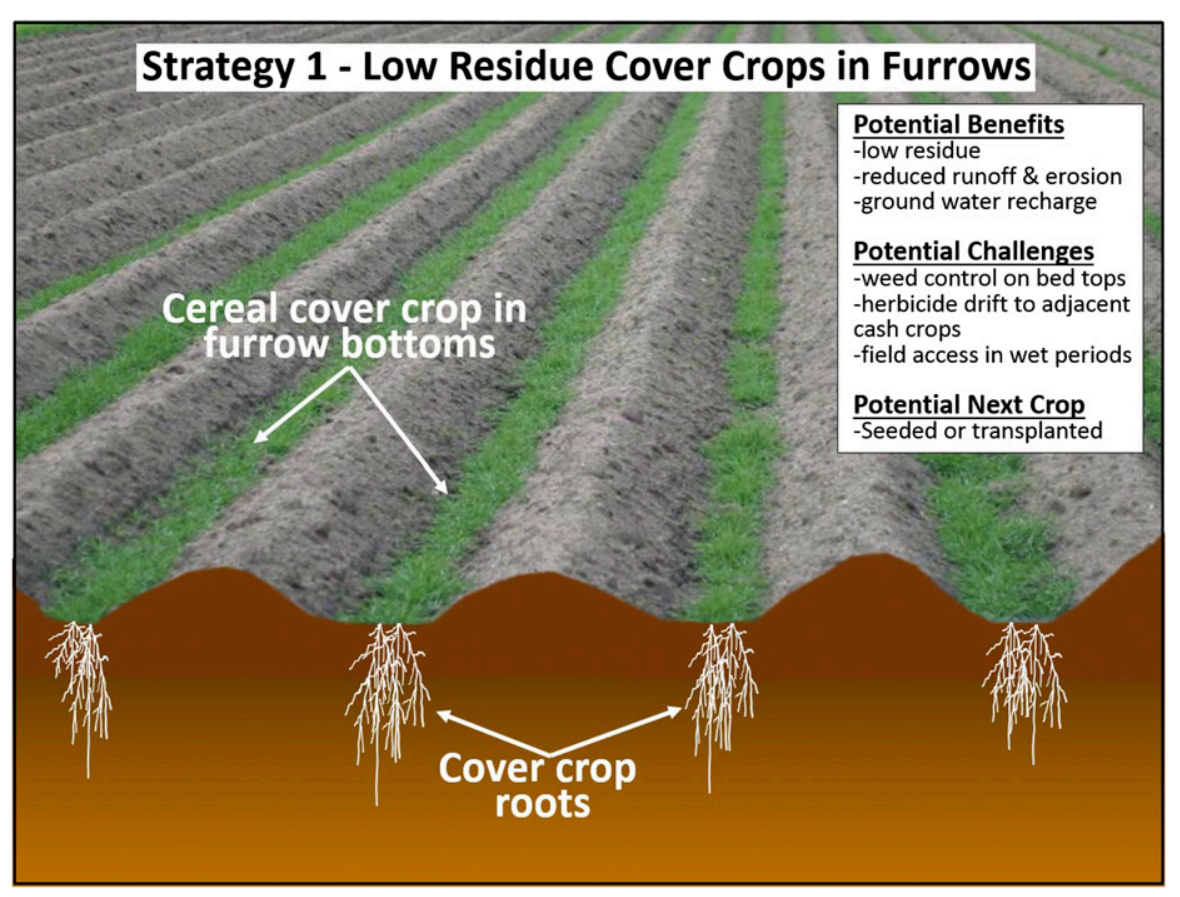

Fig. 2. Cereal cover crops are broadcast planted in an $\approx 8$ - to 12 -inch-wide band in the furrow bottoms of listed winter fallow vegetable beds and killed with a conventional herbicide after $\approx \mathbf{5 0} \mathrm{d}$ of growth. Beds are $\mathbf{4 0}$ inches wide from furrow bottom to furrow bottom and $\approx 8$ to 13 inches tall. This size bed is the industry standard for the Salinas, CA, region and are typically reformed before each vegetable crop. The root systems extending below the furrow are added for illustration purposes only; 1 inch $=2.54 \mathrm{~cm}$ (photo by R.F. Smith, illustration by E.B. Brennan).

September, established with drip irrigation, and productive until the weather cools and they are killed by frost (E.B. Brennan and J.E. Leap, unpublished data).

Getting access to fields with a tractor to cultivate weeds on bed tops or to kill the cover crop is a major challenge with this strategy, particularly if there are few dry periods during the winter. While this strategy has been promoted for several years, unfortunately, it has a low adoption rate presumably because of the cost (about \$100/acre vs. \$20/acre for bare fallowed beds) and lack of perceived short-term benefits. In contrast, interest and adoption of low-residue cover crops in strawberry fields increased markedly in recent winters in large part due to the development of a tractor drawn planter at the USDA-Agricultural Research Service (ARS) that was loaned out to farmers along with free mustard seed (Johnson, 2015). It will be interesting to see if adoption of these relatively low-residue strategies increases with increasing regulations of water quality in the Salinas Valley.
COVER CROPS ON BEDS WITH REPEATED MOWING. The pioneering work with nitrate leaching in vegetable systems in the Salinas Valley used nonlegume, winter cover crops planted in two lines on 40 -inch beds (furrow center to center) that are typically used for vegetables here (Jackson et al., 1993; Wyland et al., 1996). Even with moderate amounts of aboveground, cover crop biomass production (i.e., $3.7 \mathrm{Mg} \cdot \mathrm{ha}^{-1}$ ovendry weight), nitrate leaching was reduced by up to $70 \%$ compared with a bare winter fallow (Wyland et al., 1996). However, incorporating moderate amounts of cover crop residue into beds can be challenging, and to address this, my colleague Jim Leap and I have been experimenting with repeated mowing of cover crops on beds. The rational of this strategy is that we would be able to produce moderate amounts of biomass and therefore reduce nitrate leaching, but that the biomass would be added back to the soil surface in smaller increments than with a standard cover crop which will make it easier to incorporate the residue into the soil when the beds are prepared for the subsequent vegetable. Presumably, the live root system could capture nitrates from decomposing residue from earlier mowing. Our preliminary results suggest that cereal rye may be well suited for this strategy because of its ability to regrow multiple times after mowing. The timing of the first mowing of a mid-October-planted cereal cover crop would ideally occur in about mid-December when the shoot biomass is relatively low (i.e., about $2.5 \mathrm{Mg} \cdot \mathrm{ha}^{-1}$, or $30 \%$ of potential season-end biomass of a standard cover crop) and typically contains $\approx 80 \%$ of the total potential $\mathrm{N}$ accumulation of a standard cereal cover crop (Brennan and Boyd, 2012a, $2012 b)$. Mowing would ideally be done with a flail mower and involve cutting the cover crop as close to the bed top as possible (Fig. 3)

Cover cropping on beds with repeated mowing may be a convenient way for growers to manage evapotranspiration by cover crops through the season as needed so that the cover crop can result in a net positive water balance while achieving other important cover cropping goals such as scavenging $\mathrm{N}$, reducing runoff, and adding organic matter to the soil; the strategy might also be used with the larger 80-inch-wide beds with more rows of cover crop (Brennan and Leap, 2014). The potential effects of cover crops on groundwater recharge in relatively arid regions such as California are complex because while cover crops can protect the soil surface from crusting (Folorunso et al., 1992), which increases infiltration and reduces runoff, they also can reduce soil moisture via evapotranspiration particularly as they mature. These tradeoffs have been highlighted by studies in California and other regions with the standard cover cropping strategy (Gabriel et al., 2012; Islam et al., 2006; Joyce et al., 2002; McGuire et al., 1998; Mitchell et al., 1999, 2015; Unger and Vigil, 1998).

Planting cover crops on beds allows for mechanical weed control with blind tillage implements (i.e., rotary hoes and tine weeders) in combination with standard vegetable cultivation tools. Therefore, lower seeding rates for cover crops can be used than those that are often recommended for standard cover cropping strategies where dense stands and 


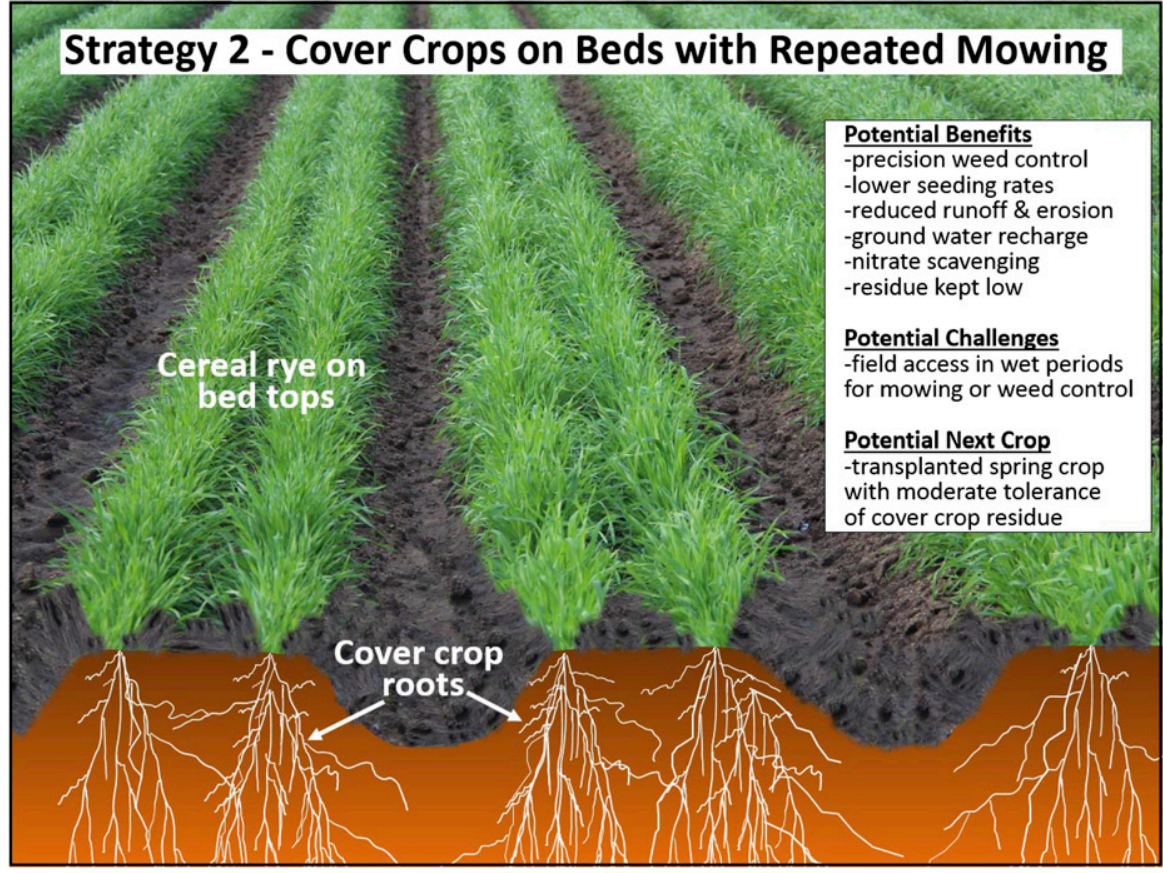

Fig. 3. Cereal cover crops are grown on the tops of winter fallow vegetable beds and repeatedly mowed to minimize the accumulation of shoot residue. The beds here are 40 inches wide from furrow bottom to furrow bottom and the cereal rye is planted in two lines spaced 12 inches apart on the bed top. The root systems extending below the beds are added for illustration purposes only. Furrow bottoms and interrow areas are cultivated to control weeds; 1 inch $=2.54 \mathrm{~cm}$ (photo and illustration by E.B. Brennan).

close row spacing are needed to suppress weed growth and seed production (Brennan et al., 2011c); lower seeding rates could potentially increase cover cropping because seed supplies for popular cereal rye varieties are often limited in California. Minimizing weed growth during winter cover crops is essential in the Salinas Valley, because many species occur year-round and seeds produced during the winter can increase the seed bank and eventually increase weeding costs in subsequent cash crops (E.B. Brennan, unpublished data). Ideally, winter cover crops on beds are established early enough in the fall to allow for several shallow cultivations to remove early weed flushes and minimize the chance of weed germination latter in the winter when the soil may be too wet to cultivate with a tractor.

There are numerous creative ways that this strategy could be modified to increase cover cropping in organic and conventional vegetable systems. For example, cover crops could be planted onto beds where the previous cash crop residue was mowed but not incorporated into the soil; however, this would not work for lettuce and celery, which must be incorporated before the mandatory host-free periods to break disease cycles in some parts of California (Wisler and Duffus, 2000). Furthermore, harvest operations would need to be managed carefully to avoid creating ruts in the field by keeping heavy equipment off of moist bed tops, and taking care not to over irrigate before harvest. In this scenario, the cover crop would germinate and grow alongside the cash crop regrowth, both which could be repeatedly mowed several times as described above. This modified strategy could have many potential benefits: 1) delayed decomposition of the previous crop residue because it would be left on the surface rather than incorporated; 2) protection from soil erosion and runoff due to the lack of fall tillage; 3 ) earlier scavenging of soil nitrate in the fall due to the presence of the live root system of the previous crop and the developing roots of the cover crop; 4) increased survival of larval stages of beneficial insects on previous crop residue left on the soil surface; 5 ) reduced seeding rates for cover crops if the lack of tillage and presence of the previous crop residue minimized the germination of a new flush of weeds. This would likely only occur in fields where there was meticulous weed control during the previous crop and therefore few weeds that survived past harvest; 6) moisture conservation due to the presence of surface residue and lack of postharvest tillage; 7) cost savings due to the lack of fall tillage.

"SHARPR" COVER CROPPING: SCAVENGE, HARVEST, PROCESS, REAPPLY. Farmers have used cover crops to improve the soil and subsequent crop yields for thousands of years (Pieters, 1927) and in many regards the typical management of cover crops in modern, tillage-intensive vegetable systems is relatively similar to how our ancestors used them (i.e., fresh biomass is incorporated back into the soil to enrich the soil and the subsequent cash crop) (Pieters and McKee, 1938). I believe that to get the most benefits from cover cropping and drastically increase their value in sustainable vegetable systems, it may be useful to radically change how we use cover crops in our modern production systems. This innovative strategy is an example of a new approach to cover cropping, which I believe has potential particularly in high-value, high-input vegetable and strawberry systems (Fig. 4).

The essential idea is to use a nonlegume cover crop like mustard to scavenge large amounts of residual $\mathrm{N}$ between about October to December, and harvest the shoot biomass when $\mathrm{N}$ uptake has peaked. In the Salinas Valley, this peak usually occurs in mid-December for cover crops that were planted in mid-October to early November (Brennan and Boyd, $2012 b)$. These cover crops would ideally be grown on bed tops as in strategy 2, but with closer between row spacing (to hasten biomass and $\mathrm{N}$ accumulation), and the biomass (about $23 \mathrm{Mg} \cdot \mathrm{ha}^{-1}$ fresh weight) would be harvested with a green chop or forage harvester to leave relatively little shoot residue on the bed surface. At this point, the biomass is typically extremely succulent with a low carbon to nitrogen ratio (9 to 12 ) and would contain at least $100 \mathrm{~kg} \cdot \mathrm{ha}^{-1} \mathrm{~N}$ (Brennan and Boyd, 2012b; Brennan et al., 2013). The biomass would be 
Strategy 3 - 'SHarPR' Cover Cropping

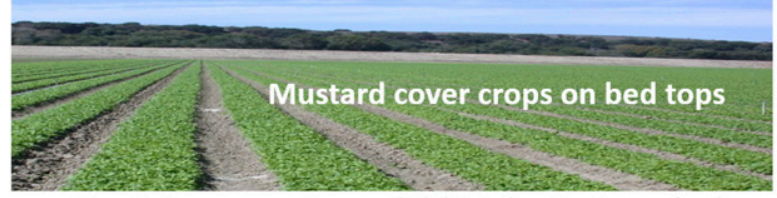

Step 1 Scavenge nitrogen (N) (October to December)

$\underline{\text { Step } 2}$ Harvest tender shoots at peak $\mathrm{N}$ accumulation

$\underline{\text { Step } 3}$ Process shoots in screw press

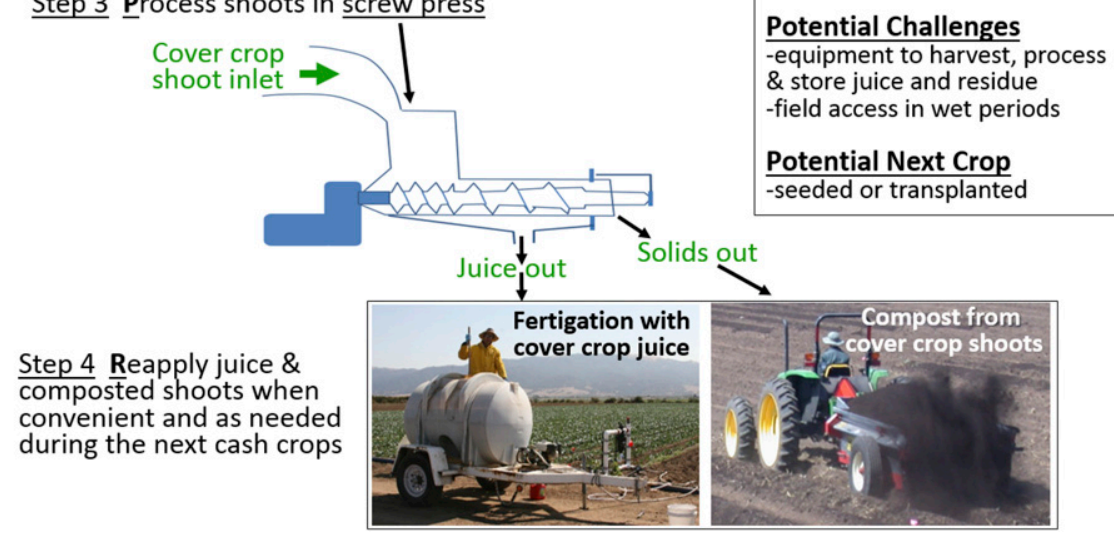

Fig. 4. A mustard cover crop is grown on the tops of winter fallow vegetable beds to scavenge leftover nitrogen $(N)$ from the previous cash crop until $N$ accumulation peaks in about mid-December. The beds shown here are 40 inches wide (furrow bottom to furrow bottom) with a dense stand of mustard planted across the bed top that is $\approx 22$ inches wide. The high- $\mathbf{N}$, tender shoots are mechanically harvested and processed through a large screw press to separate the juice and solids. The solids are processed like silage to make compost and the juice is stored for use as a liquid fertilizer during the next cash crop; 1 inch $=2.54 \mathrm{~cm}$ (photos and illustration by E.B. Brennan).

fed though an industrial-scale screw press to separate the cover crop juice from the pulp; this process is already used to dewater dairy manure. The pulp would be stored like silage or composted for application back to the field latter in the season when it was convenient (i.e., at the end of the spring vegetable crop). I estimate that $23 \mathrm{Mg} \cdot \mathrm{ha}^{-1}$ of mustard shoots would produce $\approx 14,000 \mathrm{~L} \cdot \mathrm{ha}^{-1}$ of cover crop juice and that the total $\mathrm{N}$ concentration of this liquid would be relatively low (i.e., less than 1\%) compared with typical organic liquid fertilizers (i.e., $2 \%$ to $5 \% \mathrm{~N}$ ) (E.B. Brennan, unpublished data). The cover crop juice would be stored, and processed as needed, for application as a liquid fertilizer during the subsequent vegetable crop through fertigation. The timing of fertigation events would be synchronized with the $\mathrm{N}$ demand of the vegetable crop. This strategy would be a radical change from the typical approach where cover crop residue is incorporated before cash crop planting. As my colleague Jim Leap says, this may fix the "too much at the wrong time" issue with cover crops. The lack of synchronization of cover crop nutrient release from soil-incorporated residue with vegetable crops nutrient demand is a common problem with soil fertility management with cover crops (Gaskell and Smith, 2007; Gaskell et al., 2011).

If this strategy is economically feasible, it could allow us to make far more efficient use of scavenged nutrients from cover crops in a way that enhances rather than complicates production of subsequent vegetable crops in organic or conventional systems. Because the residue would be harvested from the field in December, the beds could be reworked with minimum tillage for early vegetable planting immediately after the cover crops shoots were harvested. To achieve an economy of scale, I can envision that an agriculture service company would move from farm to farm with a mobile unit (i.e., forage harvester, screw press, and silage bagger) and leave the resulting cover crop juice and pulp at the farm where it was produced. I acknowledge that this strategy may seem impractical to some readers; however, my preliminary results and ongoing research is promising, particularly for organic systems where liquid organic fertilizers (that are often derived from fish emulsion) are extremely expensive. The acronym, SHarPR, implies that this may be a "smarter" and more precise way to use cover crops.

\section{Should vegetable farms in regions like the Salinas Valley be required to cover crop?}

During my 15 years of research on cover crops in the region, I have often wondered if farmers here should be required to cover crop a certain percentage of their acreage, primarily to reduce nitrate leaching into a common resource, the groundwater. While I wholeheartedly support the increased use of cover crops, it is important to not blindly consider them a "silver bullet" on the endless road to sustainability. Rather, I see them as one of many important pieces of this complex sustainable agriculture puzzle that we will always be trying to solve on a variety of scales. Cover crop performance is complex, because it depends on management aspects that we can control (i.e., cover crop type, seeding rate, planting date, planting arrangement, and kill date) and factors out of our control (weather). I do not believe that a "one size fits all" cover cropping requirement would solve the nitrate issue in the groundwater. I wish it was that easy. It is important to highlight that cover cropping often reduces, but does not eliminate nitrate leaching in annual cropping systems (Feaga et al., 2010; Gabriel et al., 2012; Jackson et al., 1993; Syswerda and Robertson, 2014). There is still much research and innovation needed to figure out how to grow organic and conventional vegetables sustainably with cover crops and other best management practices.

\section{Conclusion}

Over the past several decades, many papers have highlighted the benefits of cover crops in vegetable production systems (AbdulBaki et al., 1996; Brennan and Acosta-Martinez, 
2017; Campiglia et al., 2014; Creamer et al., 1997; Feaga et al., 2010; Ferris et al., 2012; Griffin et al., 2000; Hamido and Kpomblekou-A, 2009; Hartz, 2006; Heinrich et al., 2014; Hutchinson and McGiffen, 2000; Jackson and Harrison, 2008; Jackson et al., 1993; Mennan et al., 2009; Morse, 1999; Muramoto et al., 2011; Putnam and Defrank, 1983; Shennan, 1992; Snapp et al., 2005; Sorensen and Thorup-Kristensen, 2003; StiversYoung, 1998; Sumner et al., 1995; Thorup-Kristensen, 2006; Wang et al., 2008; Wang et al., 2005; Weinert et al., 2002; Wyland et al., 1996) and yet the practice is still relatively uncommon in many of the more important vegetable production regions. I am optimistic that this situation is changing and I hope that some of the novel strategies outlined here can be part of that change. I acknowledge that some of the ideas I propose are in the early stages of evaluation and may not work. In Darwinian Agriculture, Denison (2012) argued compellingly that to find the best ideas to improve agriculture "we need to generate as diverse a bunch of ideas as possible so that our selection process will have material to work with." I consider my SHarPR cover cropping strategy as one contribution to the diversity of cover cropping ideas that I hope stimulates discussion and innovation in this challenging area of agriculture. Who knows, someday we might be eating vegetables grown with cover crop juice!

There are two things that I think are critical to increase adoption and innovation of novel cover cropping strategies in vegetable production. The first is public farmland where farmers, farm advisors, and scientists can work collaboratively to evaluate, innovate, and fine-tune cover cropping (i.e., juggling) strategies suitable to the region. This has been possible at the 25 acres of USDA-ARS organic research land that I have had the pleasure to manage over the past 15 years, and which also has the unique feature of being farmed (for profit) on a commercial scale, in collaboration with local farmers. This arrangement 1) helps to offset the high cost of vegetable and strawberry production research, 2) provides an ideal site for formal field days to demonstrate novel strategies and equipment, 3) gives scientists like me a realistic understanding of day-to-day challenges that farmers face in a variety of areas (i.e., regulations, market fluctuations, labor shortages), and 4) complements innovative, and informal observational trials on private farms in the region. Second, I believe that effective and efficient communication of the "science and art" of cover cropping is critical to help busy farmers learn about novel strategies that may work in their systems. Online videos are an excellent way to achieve this and there are some excellent examples on YouTube such as "Under Cover Farmers" (USDA, 2013) that has received more than 240,000 views in 4 years. Furthermore, a recent search for the keywords "cover crops" and "vegetable" in YouTube gave $\approx 10,500$ videos, with the top 10 most relevant ones including four for the home garden scale, and six for the farm scale spanning from the Salinas Valley to the east coast of the United States including four videos by public universities and two by the USDA agencies.

The late American writer E.B. White said "A good farmer is nothing more nor less than a handy man with a sense of humus"(White, 1944). Cover crops can help us (farmers, educators, scientists, and consumers) to regain and nurture this important "sense" that can help to guide us forward to develop sustainable vegetable production systems capable of producing the nutritious dark-green vegetables that are necessary for human health with minimal negative effects on the environment.

\section{Literature cited}

AbdulBaki, A.A., J.R. Teasdale, R. Korcak, D.J. Chitwood, and R.N. Huettel. 1996. Fresh-market tomato production in a lowinput alternative system using cover-crop mulch. HortScience 31:65-69.

Adam, K.L. 2006. Community supported agriculture. 8 Apr. 2016. <https://attra. ncat.org/attra-pub/summaries / summary.php?pub=262>.

Bowles, T.M., V. Acosta-Martinez, F. Calderon, and L.E. Jackson. 2014. Soil enzyme activities, microbial communities, and carbon and nitrogen availability in organic agroecosystems across an intensivelymanaged agricultural landscape. Soil Biol. Biochem. 68:252-262.

Brennan, E.B. 2014. Are legume-cereal mixtures a good fit for organic vegetable production? 6 Feb. 2016. <https://www. youtube.com/watch?v=WREmHa-jFbc $>$.

Brennan, E.B. and V. Acosta-Martinez. 2017. Cover cropping frequency is the main driver of soil microbial changes during six years of organic vegetable production. Soil Biol. Biochem. 109:188-204.

Brennan, E.B. and N.S. Boyd. 2012a. Winter cover crop seeding rate and variety affects during eight years of organic vegetables: I. Cover crop biomass production. Agron. J. 104:684-698.

Brennan, E.B. and N.S. Boyd. 2012b. Winter cover crop seeding rate and variety affects during eight years of organic vegetables: II. Cover crop nitrogen accumulation. Agron. J. 104:799-806.

Brennan, E.B., N.S. Boyd, and R.F. Smith. 2013. Winter cover crop seeding rate and variety affects during eight years of organic vegetables: III. Cover crop residue quality and nitrogen mineralization. Agron. J. 105:171-182.

Brennan, E.B., N.S. Boyd, R.F. Smith, and P. Foster. 2011a. Comparison of rye and legume-rye cover crop mixtures for vegetable production in California. Agron. J. 103:449-463.

Brennan, E.B., N.S. Boyd, R.F. Smith, and P. Foster. 2011b. Seeding rate and planting arrangement effects on growth and weed suppression of a legume-oat cover crop for organic vegetable systems. Agron. J. 103:1565.

Brennan, E.B., O. Daugovish, R.F. Smith, and S.A. Fennimore. 2011c. Weeds, p. 43-46. In: R.F. Smith, R.L. Bugg, O. Daugovish, M. Gaskell, and M. Van Horn (eds.). Cover cropping for vegetable production: A grower's handbook. Univ. California, Oakland, CA.

Brennan, E.B. and J.E. Leap. 2014. A comparison of drill and broadcast methods for establishing cover crops on beds. HortScience 49:441-447.

Brennan, E.B., S.B. Mirsky, and M. Cavigelli. 2014. Cover cropping is like juggling. 6 Feb. 2016. <https://www. youtube.com/watch?v=Z8yVDphBm78>.

Buck, D., C. Getz, and J. Guthman. 1997. From farm to table: The organic vegetable commodity of northern California. Sociol. Ruralis 37:3-20.

Bustamante, S.C. and T.K. Hartz. 2015. Nitrogen management in organic processing tomato production: Nitrogen sufficiency prediction through early-season soil and plant monitoring. HortScience 50:1055-1063.

Buzby, J.C., H.F. Wells, and G. Vocke. 2006. Possible implications for U.S. agriculture from adoption of select dietary 
guidelines. 9 Mar. 2016. <http://www. ers.usda.gov/media/860109/err31_ 002.pdf>.

Cahn, M.D. and G. Miyao. 2011. Water management and impact on water quality, p. 31-36. In: R.F. Smith, R.L. Bugg, O. Daugovish, M. Gaskell, and M. Van Horn (eds.). Cover cropping for vegetable production: A grower's handbook. Univ. California, Oakland, CA.

Cahn, M., R. Smith, and A. Young. 2006. Evaluation of practices for controlling storm run-off from vegetable fields. $8 \mathrm{Feb}$. 2016. <http://cemonterey.ucanr.edu/ newsletters /November-December, 200632272.pdf>.

Campiglia, E., R. Mancinelli, V. Di Felice, and E. Radicetti. 2014. Long-term residual effects of the management of cover crop biomass on soil nitrogen and yield of endive (Cichorium endivia L.) and savoy cabbage (Brassica oleracea var. sabauda). Soil Tillage Res. 139:1-7.

Creamer, N.G., M.A. Bennett, and B.R. Stinner. 1997. Evaluation of cover crop mixtures for use in vegetable production systems. HortScience 32:866-870.

Dara, S.K., K.M. Klonsky, and K.P. Tumber. 2012. Sample costs to produce fresh market broccoli. 9 Mar. 2016. $<$ http://coststudyfiles.ucdavis.edu/ uploads/cs_public/84/2e/842e78c33 f 2 c- $4595-$ ab 4 b- 230 b 89 b $24150 /$ broccoli_cc2012.pdf>.

Davidson, E.A., E.C. Suddick, C.W. Rice, and L.S. Prokopy. 2015. More food, low pollution (Mo Fo Lo Po): A grand challenge for the 21 st century. J. Environ. Qual. 44:305-311.

Denison, R.F. 2012. Darwinian agriculture. Princeton Univ. Press, Princeton, NJ.

Di, H.J. and K.C. Cameron. 2002. Nitrate leaching in temperate agroecosystems: Sources, factors and mitigating strategies. Nutr. Cycl. Agroecosyst. 46:237-256.

Drinkwater, L.E. and S.S. Snapp. 2007. Nutrients in agroecosystems: Rethinking the management paradigm. Adv. Agron. 92:163-186.

Dunn, M., J.D. Ulrich-Schad, L.S. Prokopy, R.L. Myers, C.R. Watts, and K. Scanlon. 2016. Perceptions and use of cover crops among early adopters: Findings from a national survey. J. Soil Water Conserv. 71:2940 .

Feaga, J.B., J.S. Selker, R.P. Dick, and D.D. Hemphill. 2010. Long-term nitrate leaching under vegetable production with cover crops in the Pacific Northwest. Soil Sci. Soc. Amer. J. 74:186-195.

Ferris, H., S. Sanchez-Moreno, and E.B. Brennan. 2012. Structure, functions and interguild relationships of the soil nematode assemblage in organic vegetable production. Appl. Soil Ecol. 61:16-25.

Folorunso, O.A., D.E. Rolston, T. Prichard, and D.T. Louie. 1992. Soil surface strength and infiltration-rate as affected by winter cover crops. Soil Technol. 5:189-197.

Gabriel, J.L., R. Munoz-Carpena, and M. Quemada. 2012. The role of cover crops in irrigated systems: Water balance, nitrate leaching and soil mineral nitrogen accumulation. Agr. Ecosyst. Environ. 155:50 61.

Gaskell, M. and R. Smith. 2007. Nitrogen sources for organic vegetable crops. HortTechnology 17:431-441.

Gaskell, M., R. Smith, L.E. Jackson, and T.K. Hartz. 2011. Soil nitrogen fertility management, p. 37-40. In: R.F. Smith, R.L. Bugg, O. Daugovish, M. Gaskell, and M. Van Horn (eds.). Cover cropping for vegetable production: A grower's handbook. Univ. California, Oakland, CA.

Griffin, T., M. Liebman, and J. Jemison. 2000. Cover crops for sweet corn production in a short-season environment. Agron. J. 92:144-151.

Guthman, J. 2000. Raising organic and agro-ecological assessment of grower practices in California. Agr. Human Values 17:257-266.

Guthman, J. 2004. The trouble with 'organic lite' in California: A rejoinder to the 'conventionalisation' debate. Sociol. Ruralis 44:301-316.

Hamido, S.A. and K. Kpomblekou-A. 2009. Cover crop and tillage effects on soil enzyme activities following tomato. Soil Tillage Res. 105:269-274.

Harter, T., J.R. Lund, J. Darby, G.E. Fogg, R. Howitt, K.K. Jessoe, G.S. Pettygrove, J.F. Quinn, J.H. Viers, D.B. Boyle, H.E. Canada, N. DeLaMora, K.N. Dzurella, A. Fryjoff-Hung, A.D. Hollander, K.L. Honeycutt, M.W. Jenkins, V.B. Jensen, A.M. King, G. Kourakos, D. Liptzin, E.M. Lopez, M.M. Mayzelle, A McNally, J. Medellin-Azuara, and R.T.S. 2012. Addressing nitrate in California's drinking water with a focus on Tulare Lake basin and Salinas Valley groundwater. 9 Mar. 2016. <http://groundwaternitrate. ucdavis.edu/files/138958.pdf>.

Hartz, T.K. 2002. Sustainable vegetable production in California: Current status, future prospects. HortScience 37:10151022 .

Hartz, T.K. 2006. Vegetable production best management practices to minimize nutrient loss. HortTechnology 16:398403.
Hartz, T.K. and P.R. Johnstone. 2006. Nitrogen availability from high-nitrogencontaining organic fertilizers. HortTechnology 16:39-42.

Heinrich, A., R. Smith, and M. Cahn. 2014. Winter-killed cereal rye cover crop influence on nitrate leaching in intensive vegetable production systems. HortTechnology 24:502-510.

Hutchinson, C.M. and M.E. McGiffen. 2000. Cowpea cover crop mulch for weed control in desert pepper production. HortScience 35:196-198.

Islam, N., W.W. Wallender, J. Mitchell, S. Wicks, and R.E. Howitt. 2006. A comprehensive experimental study with mathematical modeling to investigate the affects of cropping practices on water balance variables. Agr. Water Mgt. 82:129147.

Jackson, D.M. and H.F. Harrison. 2008. Effects of a killed-cover crop mulching system on sweetpotato production, soil pests, and insect predators in South Carolina. J. Econ. Entomol. 101:18711880 .

Jackson, L.E., L.J. Wyland, and L.J. Stivers. 1993. Winter cover crops to minimize nitrate losses in intensive lettuce production. J. Agr. Sci. 121:55-62.

Johnson, B. 2015. October 21. Machine helps with cover crops for runoff control. 2 Apr. 2016. <http://www.agalert.com/ story $/$ ? id $=8867>$.

Joyce, B.A., W.W. Wallender, J.P. Mitchell, L.M. Huyck, S.R. Temple, P.N. Brostrom, and T.C. Hsiao. 2002. Infiltration and soil water storage under winter cover cropping in California's Sacramento Valley. Trans. Amer. Soc. Agr. Eng. 45:315-326.

Kirchmann, H. and L. Bergstrom. 2001. Do organic farming practices reduce nitrate leaching? Commun. Soil Sci. Plant Anal. 32:997-1028.

Klonsky, K. and L. Tourte. 2011. Economics, p. 83-85. In: R.F. Smith, R.L. Bugg, O. Daugovish, M. Gaskell, and M. Van Horn (eds.). Cover cropping for vegetable production: A grower's handbook. Univ. California, Oakland, CA.

McGuire, A.M., D.C. Bryant, and R.F. Denison. 1998. Wheat yields, nitrogen uptake, and soil moisture following winter legume cover crop vs. fallow. Agron. J. 90:404-410

Medellin-Azuara, J., T.S. Rosenstock, R.E. Howitt, T. Harter, K.K. Jessoe, K. Dzurella, S. Pettygrove, and J.R. Lund. 2013. Agroeconomic analysis of nitrate crop source reductions. J. Water Resources Plan. Mgt. 139:501-511. 
Meisinger, J.J., W.L. Hargrove, R.L. Mikkelson, and V.W. Benson. 1991. Effects of cover crops on groundwater quality, p. 57-68. In: W.L. Hargrove (ed.). Cover crops for clean water. Soil Water Conservation Soc., Jackson, TN.

Mennan, H., M. Ngouajio, E. Kaya, and D. Isik. 2009. Weed management in organically grown kale using alternative cover cropping systems. Weed Technol. 23:81-88.

Mitchell, J.P., D.W. Peters, and C. Shennan. 1999. Changes in soil water storage in winter fallowed and cover cropped soils. J. Sustain. Agr. 15:19-31.

Mitchell, J.P., A. Shresta, and S. Irmak. 2015. Trade-offs between winter cover crop production and soil water depletion in the San Joaquin Valley, California. J. Soil Water Conserv. 70:430-440.

Monterey County Agricultural Commissioner. 2013. Monterey County crop report 2013. 9 Mar. 2016. <http://ag.co. monterey.ca.us/assets /resources/ assets /252/cropreport_2012.pdf>.

Monterey County Agricultural Commissioner. 2014. Monterey County crop report 2014. 4 Oct. 2012. <http://ag.co. monterey.ca.us/assets/resources/assets/ 252/cropreport_2014.pdf>.

Morse, R.D. 1999. No-till vegetable production - Its time is now. HortTechnology 9:373-379.

Muramoto, J., R. Smith, C. Shennan, K. Klonsky, J. Leap, M. Silva Ruiz, and S. Gliessman. 2011. Nitrogen contribution of legume/cereal mixed cover crops and organic fertilizers to an organic broccoli crop. HortScience 46:1154-1162.

Patz, J.A., D. Engelberg, and J. Last. 2000. The effects of changing weather on public health. Annu. Rev. Public Health 21:271-307.

Pieters, A.J. 1927. Green manuring. Principles and practices. Wiley, New York, NY.

Pieters, A.J. and R. McKee. 1938. The use of cover and green-manure crops, p. 431444. Soils and men. Yearbook of agriculture. U.S. Dept. Agr., Washington, DC.

Putnam, A.R. and J. Defrank. 1983. Use of phytotoxic plant residues for selective weed-control. Crop Prot. 2:173-181.

Rosenstock, T.S., D. Liptzin, K. Dzurella, A. Fryjoff-Hung, A. Hollander, V. Jensen, A. King, G. Kourakos, A. McNally, G.S. Pettygrove, J. Quinn, J.H. Viers, T.P. Tomich, and T. Harter. 2014. Agriculture's contribution to nitrate contamination of Californian groundwater (1945-2005). J. Environ. Qual. 43:895907.
Schipanski, M.E., M. Barbercheck, M.R. Douglas, D.M. Finney, K. Haider, J.P. Kaye, A.R. Kemanian, D.A. Mortensen, M.R. Ryan, J. Tooker, and C. White. 2014. A framework for evaluating ecosystem services provided by cover crops in agroecosystems. Agr. Syst. 125:12-22.

Shennan, C. 1992. Cover crops, nitrogen cycling, and soil properties in semiirrigated vegetable production systems. HortScience 27:749-754.

Shepherd, M. and B. Chambers. 2007. Managing nitrogen on the farm: The devil is in the detail. J. Sci. Food Agr. 87:558568.

Singer, J.W. and S.M. Nusser. 2007. Are cover crops being used in the US corn belt? J. Soil Water Conserv. 62:353358 .

Smith, R., M. Cahn, A. Heinrch, and B. Farrara. 2011. Low residue cover crops for winter fallow vegetable production fields: Summary of two years of evaluations. $8 \mathrm{Feb}$. 2016. <http://cemonterey.ucanr.edu/ newsletters/_i__b_Monterey_County_ Crop_Notes_b____41658.pdf $>$.

Smith, R.F. and M. Cahn. 2007. Winter cover crops: Strategies for including them in Salinas Valley vegetable rotations. 8 Feb. 2016. <http://cemonterey.ucanr. edu/newsletters/September_-_October_ 200732265.pdf>.

Snapp, S.S., S.M. Swinton, R. Labarta, D. Mutch, J.R. Black, R. Leep, J. Nyiraneza, and K. O'Neil. 2005. Evaluating cover crops for benefits, costs and performance within cropping system niches. Agron. J. 97:322-332.

Sorensen, J.N. and K. Thorup-Kristensen. 2003. Undersowing legume crops for green manuring of lettuce. Biol. Agr. Hort. 21:399-414.

Stivers-Young, L. 1998. Growth, nitrogen accumulation, and weed suppression by fall cover crops following early harvest of vegetables. HortScience 33:60-63.

Sumner, D.R., S.C. Phatak, J.D. Gay, R.B. Chalfant, K.E. Brunson, and R.L. Bugg. 1995. Soilborne pathogens in a vegetable double-crop with conservation tillage following winter cover crops. Crop Prot. 14:495-500.

Sustainable Agriculture Research and Education. 2010. What is sustainable agriculture? 8 Apr. 2016. <http://www.sare. org/Learning-Center/SARE-ProgramMaterials/National-Program-Materials/ What-is-Sustainable-Agriculture $>$.

Sutherland, L.A. 2013. Can organic farmers be 'good farmers'? Adding the 'taste of necessity' to the conventionalization debate. Agr. Human Values 30:429-441.

Syswerda, S.P. and G.P. Robertson. 2014. Ecosystem services along a management gradient in Michigan (USA) cropping systems. Agr. Ecosyst. Environ. 189:2835.

Thaler, R.H. and C.R. Sustein. 2008. Saving the planet, p. 183-196. Nudge: Improving decisions about health, wealth, and happiness. Yale Univ. Press, New Haven, CT.

Thorup-Kristensen, K. 2006. Root growth and nitrogen uptake of carrot, early cabbage, onion and lettuce following a range of green manures. Soil Use Mgt. 22:29-38.

Tourte, L., R.F. Smith, K. Klonsky, D. Sumner, C. Gutierrez, and D. Steward. 2015. Sample costs to produce and harvest romaine hearts. 9 Mar. 2016. <http://coststudyfiles.ucdavis.edu/ uploads/cs_public/50/a0/50a0bad6l cf0 - 4 d 6 1 - a 632-78b6fe 2 ff $538 /$ 2015 romainehearts-finaldraft_1-272016-1.pdf>.

Unger, P.W. and M.F. Vigil. 1998. Cover crop effects on soil water relationships. J. Soil Water Conserv. 53:8.

U.S. Department of Agriculture (USDA). 2013. Under cover farmers. 7 Feb. 2016. <https://www.youtube.com/watch? $\mathrm{v}=\mathrm{nWXCLVCJWTU}>$.

U.S. Department of Agriculture (USDA). 2014. 2012 Census of agriculture. 9 Feb. 2016. <http://www.agcensus.usda.gov/ Publications/2012/Full_Report/ Volume_1,_Chapter_1_US/usvl.pdf $>$.

U.S. Department of Agriculture (USDA). 2015. Dietary guidelines for Americans. 2015-2020.9 Feb. 2016. <http:// health.gov/dietaryguidelines/2015/ guidelines $/>$.

Wall, D.H., U.N. Nielsen, and J. Six. 2015. Soil biodiversity and human health. Nature 528:69-76.

Wang, G.Y., M. Ngouajio, M.E. McGiffen, and C.M. Hutchinson. 2008. Summer cover crop and in-season management system affect growth and yield of lettuce and cantaloupe. HortScience 43:13981403.

Wang, Q.R., W. Klassen, Y.C. Li, M. Codallo, and A.A. Abdul-Baki. 2005. Influence of cover crops and irrigation rates on tomato yields and quality in a subtropical region. HortScience 40:21252131.

Weinert, T.L., W.L. Pan, M.R. Moneymaker, G.S. Santo, and R.G. Stevens. 2002. Nitrogen recycling by nonleguminous winter 
cover crops to reduce leaching in potato rotations. Agron. J. 94:365-372.

White, E.B. 1944. The practical farmer, p. 159-169. In: K. Hall and M.E. Thorndike (eds.). One man's meat. 1997 large print ed.
Wisler, G.C. and J.E. Duffus. 2000. A century of plant virus management in the Salinas Valley of California, 'East of Eden'. Virus Res. 71:161-169.

Wyland, L.J., L.E. Jackson, W.E. Chaney, K. Klonsky, S.T. Koike, and B. Kimple.
1996. Winter cover crops in a vegetable cropping system: Impacts on nitrate leaching, soil water, crop yield, pests and management costs. Agr. Ecosyst. Environ. 59:1-17. 